\title{
REDUCTION OF CORRUPTION BY LIMITING THE DISCRETION OF OFFICIALS
}

[Snižování korupce prostřednictvím omezování diskreční pravomoci úředníků]

\author{
Veronika Linhartová ${ }^{1}$ \\ ${ }^{1}$ Univerzita Pardubice, Fakulta ekonomicko-správní, Studentská 95, 53210 Pardubice \\ Email:veronika.linhartova@upce.cz
}

\begin{abstract}
Fighting corruption is very challenging and difficult. Due to the fact that bribery and other forms of corruption are illegal practices in most countries, the actors of corruption are trying to hide their behavior and revelation of corruption is almost impossible. The most discussed is corruption in the public sector, because the consequences of such abuse of public power hit the broad mass of taxpayers and the state in general. For this reason efforts to reduce corruption are focused mainly on public administration. For reducing the interaction between officials and the public could be use e-government methods as a possible way to reduce corruption. The literature focused on e-government methods in relation to corruption suggests that electronic service delivery can reduce corruption by minimizing the interactions with officials, accelerating decisions and reducing human errors. This paper is focused on the potential role of e-government in reducing the level of corruption in the country. Specifically, this paper examines the impact of the use of e-government methods on the level of corruption in 117 countries all over the world.
\end{abstract}

Keywords: corruption, Corruption Perception Index, Development Index, discretion, E-Government, public officials.

JEL classification: D73, H11

Doručeno redakci: 10.3.2015; Recenzováno: 22.3.2015; 22.4.2015; Schváleno k publikování: 23.9.2015

\section{Úvod}

Studie zaměřené na téma korupce za poslední dekádu ukázaly, že korupce odrazuje od investic, omezuje hospodářský růst, mění složení vládních výdajů, podkopává vládní snahy o snížení chudoby a brání zlepšení kvality života ve venkovských a chudých částech rozvojových zemí (Bhargava, Bolongaita, 2004 a Jain, 2001), (Mauro, 1995 a Tanzi, 1998). To jsou hlavní důvody, proč vlády jednotlivých zemí vynakládají značné finanční a jiné zdroje za účelem vybudování efektivní antikorupční politiky. Možným způsobem snižování korupce, zejména ve veřejném sektoru, může být snižování vzájemných interakcí mezi úředníky a veřejností. Toho může být dosaženo prostřednictvím metod e-governmentu. E-government umožňuje nejen jednoduše poskytovat více informací obyvatelstvu, ale pomáhá odstranit diskreční pravomoc úředníků, tedy pravomoc úředníků rozhodovat podle vlastního posouzení situace (Hopper et al, 2009).

Cílem tohoto př́spěvku je potvrdit či vyvrátit vztah mezi úrovní korupce a stupněm využívání metod e-governmentu v zemi. V příspěvku bude testován vztah, do jaké míry souvisí změny ve využívání e-governmentu se změnami v míre korupce zvoleného souboru zemí.

\section{Omezování diskreční pravomoci úředníků jako možná cesta ke snížení míry korupce}

Korupce se stala velmi diskutovaným tématem, jež trápí vlády jednotlivých zemí i občany samotné. Přestože korupce není nijak novým jevem, jednoznačná definice, jež by byla uznávána $v$ řadách laické i odborné veřejnosti prozatím neexistuje. Odlišné vnímání tohoto pojmu vedlo k vytvoření celé řady definic. Světová banka vytvořila v současné době zřejmě nejznámější definici, podle níž je korupce zneužití veřejné moci k soukromému prospěchu. 
(Hellmann, Jones, Kaufmann, 2009). Uvedená definice korupce se zaměřuje zejména na zneužití veřejné moci, tedy poněkud opomíjí korupci $\mathrm{v}$ soukromém sektoru, která samozřejmě také existuje. Většina studií je však zaměřena na korupci v sektoru veřejném, a to $\mathrm{z}$ jednoduchého důvodu - důsledky takového zneužití veřejné moci dopadají na širokou masu všech daňových poplatníků a stát jako takový. Korupce ve veřejném sektoru může způsobovat zvyšování veřejných výdajů a snižování objemu vybíraných daní, čímž se zvýší fískální deficity a vytváří makroekonomická nestabilita (Mauro, 1997 a Bhargava, Bolongaita, 2004).

Některé studie identifikují potenciální cestu omezování korupčních aktivit v omezování diskrečních pravomocí úředníků pomoci využití metod e-governmentu. E-government se stal zastř̌šujícím pojmem zahrnujícím veškeré využívání informačních a komunikačních technologií (dále již pouze ICT) ve státní správě a zahrnuje sdílení informací a provádění transakcí v rámci vlády $(\mathrm{G} 2 \mathrm{G})$, mezi vládou a podniky $(\mathrm{G} 2 \mathrm{~B})$ a mezi vládou a občanem (G2C) na podkladě těchto technologií. Torres, Pina, Acerate (2006), Andersen a Rand (2006) studovali vztah mezi korupcí a e-governmentem a došli k závěru, že dobře koncipované politiky v oblasti ICT mohou být účinné v boji proti korupci. Shin a Eom (2008) se zaměřují na faktory byrokratické profesionality a kvality byrokracie a rovněž zjistili, že e-government má pozitivní vliv na tyto proměnné. V návaznosti na zmiňovaný výzkum Shim a Eom (2009) zkoumali dopad ICT a sociálního kapitálu na korupci a potvrdili, že ICT má potenciál snížit zbytečné lidské zásahy do veřejných procesů, což snižuje potřebu korupčního chování. Pro výzkum využívali panely datových souborů $\mathrm{z}$ různých zdrojů a dospěli $\mathrm{k}$ závěru, že informační a komunikační technologie jsou účinným nástrojem ke snižování korupce v zemi. E-government omezuje prostor pro uplácení odstraněním zprostředkovatelských služeb a umožňuje občanům vyřídit si své záležitosti svépomocí (Singh, Pathak, Naz, Belwal, 2010).

Výzkumy provedené $\mathrm{v}$ této oblasti ukazují, že faktory podporující korupční praktiky u pracovníků veřejné správy, jako je např́ílad monopol moci, diskreční pravomoc či nedostatek odpovědnosti jsou zmírněny existencí fungujícího právního systému a větší transparentností (Mistry, 2012). Tyto studie se shodují na tom, že větší využívání e-governmentu může oslabit faktory vyvolávající korupční jednání a mají za následek snižování monopolní moci úředníků a v konečném důsledku vedou $\mathrm{k}$ větší transparentnosti činností ve veřejné správě (Kimbro, 2002 a Kim, 2007).

Uvedení autoři se $\mathrm{v}$ zásadě shodují, že důležitou roli $\mathrm{v}$ protikorupčních strategiích jednotlivých států hraje poskytování snadného přistupu $\mathrm{k}$ informacím pro všechny občany prostřednictvím využití e-government př́istupů a iniciativ. To může mít za následek větší transparentnost činností, která omezuje možnost veřejného úředníka přijímat či dokonce vyžadovat úplatek.

Konkrétní příklady fungujícího využití e-governmentu jako nástroje pro boj s korupcí lze nalézt $\mathrm{v}$ řadě zemí bez ohledu na jejich ekonomickou vyspělost, politické zrrízení či geografickou polohu. Např́klad ve Spojených státech amerických je dobrým prŕkladem využití e-governmentu jako nástroje pro omezování korupčních prŕíležitostí činnost Střediska pro odpovědnou politiku (The Center for Responsive Politics). Jedná se o nevládní neziskovou organizaci, která se orientuje na sledování finančních toků pro oblast veřejných politik. Středisko sleduje efekty finančních toků a lobbingu na volby a oblast veřejných politik a za účelem informování a zapojení široké veřejnosti provozuje online databázi informací o sledovaných aktivitách. Databáze umožňuje uživatelům sledovat federální př́spěvky na volební kampaně, činnosti lobbistických organizací, individuálních lobbistů apod. Obsahuje rovněž osobní finanční výkazy prezidenta, členů amerického Kongresu, 
či vedoucích pracovníků významných orgánů veřejné správy. Uživatelé databáze mohou také na základě poštovních směrovacích čísel sledovat, jak jejich sousedé alokovali politické př́spěvky. Projekt Bhoomi je společně financovaný vládou Indie a vládou státu Karnataka za účelem digitalizace pozemkových záznamů v původní papírové podobě a vytvořit software pro řízení změn v katastru nemovitostí v oblasti Karnataka. Projekt byl navržen tak, aby eliminoval dlouhotrvající problém neefektivnosti a korupce při správě pozemkových záznamů v rozptýlené a špatně kontrolované oblasti v Indii. Bhoomi snížil diskreční pravomoc veřejných činitelů zavedením striktních pravidel pro vytváření online záznamů o vlastnictví a správě pozemků. Zemědělci nyní mohou přistupovat $\mathrm{k}$ databázi a jsou oprávněni údaje o svých pozemcích sledovat. V rámci projektu Bhoomi bylo rovněž vytvořeno několik informačních kiosků, na nichž si zemědělci mohou za poplatek vytisknout údaje o vlastníkovi pozemku či číslo dané parcely, které potřebují například pro získání úvěru (Bhatnagar, 2003).

\section{Popis metodiky a použitých indikátorů}

Za účelem ověření existence vztahu mezi mírou korupce a mírou využití e-governmentu budou analyzovány zavedené indexy měřící míru korupce a využití e-governmentu v zemi. Analyzovanou časovou řadou je období let 2003 až 2011. Jedná se nejdelší časovou řadu, kterou je s využitím zvolených ukazatelů možno analyzovat. V roce 2003 byl poprvé publikován zvolený ukazatel úrovně e-governmentu $\mathrm{v}$ zemi a rok 2011 je posledním rokem, kdy byla u ukazatele měř́cího míru korupce $\mathrm{v}$ zemi využita jeho původní metodika konstrukce ukazatele.

Jako indikátor měřící míru korupce v zemi byl pro analýzu zvolen ukazatel Index vnímání korupce (Corruption Perception Index, CPI), jež je publikován organizací Transparency International již od roku 1995. Jedná se o Index, který je založen na vnímání korupce respondenty šetření, jimiž jsou domácí i zahraniční podnikatelé, analytici a zástupci odborné veřejnosti z hodnocených zemí. Index je publikován jednou ročně a průzkumy použité při jeho sestavování většinou obsahují otázky zaměřené na uplácení veřejných činitelů nebo provize při veřejných zakázkách. Ve sledovaném období nabýval CPI hodnoty v intervalu $\langle 0 ; 10\rangle^{1}$, kde 0 představuje zemi velmi zkorumpovanou a hodnota 10 značí zemi bez korupce. Vzorek zkoumaných zemí se v průběhu času měnil. Např́íklad v roce 1995 bylo zahrnuto 41 zemí, v průzkumu z roku 2011 jich bylo již 183. Měnící se počet hodnocených zemí je důvodem, proč při posuzování jednotlivých zemí není důležité jejich pořadí v žebříčku, ale samotná hodnota CPI. Rozsah korupce v každé zemi hodnotí dvě skupiny. První tvoří odborníci na danou zemi, a to jak její rezidenti, tak zahraniční experti, druhou tvoří přední představitelé podnikatelského sektoru. Pro index CPI 2011 byly využity údaje vycházející z odborného hodnocení z následujících sedmi zdrojů: African Development Bank, Asian Development Bank, Bertelsmann Foundation, Economist Intelligence Unit, Freedom House, Global Insight, Political Risk Services, the World Bank and the World Justice Project. Další čtyři zdroje údajů pro index CPI 2011 odrážejí hodnocení předních manažerů, kteří jsou rezidenty hodnocené země: IMD, Political and Economic Risk Consultancy, Transparency International's Bribe Payers Survey a World Economic Forum (Transparency International, 2011).

Index rozvoje e-governmentu (E-government Development Index, EGDI) se používá $\mathrm{k}$ získání odhadu úrovně e-governmentu $\mathrm{v}$ dané zemi. Toto měření je založeno na průzkumech sestavených za spolupráce OSN-UNDESA (United Nations Department of Economic and Social Affairs) a Civic Resource Group, poradenskou firma poskytující technologická řešení

\footnotetext{
${ }^{1}$ Od roku 2012 nabývá hodnot v intervalu $\left.<0 ; 100\right\rangle$.
} 
v oblasti e-governmentu. Rámec EGDI byl koncipován jako součást Deklarace tisíciletí OSN a zahrnuje jak stav e-government připravenosti, tak rozsah e-participace. EGDI odráží, jak země využívá informačních technologií na podporu př́stupu a začlenění jejích obyvatel. EGDI je složen ze tř́i různých indexů: (United Nations, 2011)

- Web Measure Index,

- Telecommunication Infrastructure Index

- Human Capital Index

Web Measure Index představuje obecnou schopnost vlád využívat e-government jako nástroj pro informování, komunikaci, přenos dat apod.. Telecommunication Infrastructure Index definuje IT kapacitu dané země a Human Capital Index vychází ze "Vzdělávacího indexu" Rozvojového programu OSN měřícího úroveň rozvoje lidského kapitálu v zemi.

EGDI byl sestaven poprvé $\mathrm{v}$ roce 2003 a nabývá intervalu $<0 ; 1>$, kde hodnota jedné představuje vysokou úroveň využití metod e-governmentu a nulová hodnota Indexu značí naopak nízkou míru aplikace zmiňovaných metod v oblasti veřejné správy.

Ověření existence vztahu mezi mírou využití e-governmentu a mírou korupce, bude provedeno za pomoci jednoduché lineární regresní analýzy a korelačního koeficientu. Korelační vztah mezi definovanými veličinami vstupující do analýzy bude verifikován pomocí hodnoty Spearmanova koeficientu korelace (dále jen „koeficient korelace“). Výpočet hodnoty korelačního koeficientu bude proveden pomocí statistického softwaru STATISTICA verze 10.1. Hladina významnosti stanovená pro korelační analýzu je standardní, tedy 0,05 .

V procesu výpočtu bude nejprve definována nulová hypotéza, která vymezuje, že mezi sledovanými veličinami není korelační vztah. Verifikace stanovené hypotézy vychází z následného porovnání stanovené hladiny významnosti s hodnotou, kterou generuje statistický software, tzv. p-hodnotou. Následně lze též určit, jak těsný je vzájemný korelační vztah mezi sledovanými veličinami, a to prímo z hodnoty koeficientu korelace. Koeficient korelace může nabývat hodnoty v rozmezí -1 a 1 včetně. V př́padě, že se blíží hodnota koeficientu korelace $\mathrm{k}$ hodnotě -1 , resp. 1, lze hovořit o velmi silném vzájemném korelačním vztahu mezi sledovanými veličinami. Dále lze odlišit pozitivní korelační vztah (resp. př́mý vztah), který nastává v př́ípadě, že hodnota koeficientu korelace nabývá kladných hodnot. Anebo v opačném případě se jedná o negativní korelační vztah (resp. nepřímý vztah).

$\mathrm{V}$ provedených analýzách bude nejprve zkoumána existence vztahu mezi EGDI a CPI ve dvou časových obdobích (tj. v roce 2003 a v roce 2011). Následně bude analyzováno, zda existuje vztah mezi změnou v EGDI a změnou CPI během zmiňovaného období. Ve všech provedených analýzách vystupuje ukazatel CPI jako závisle proměnná a EGDI jako určující nezávisle proměnná.

Většina existujících studií zabývajících se vlivem e-governmentu se orientuje na analýzu tohoto vlivu u rozvojových zemí a poněkud opomíjí možné působení e-governmentu na snižování korupce ve vyspělejších zemích. Důvod je zřejmý, míra korupce mezi předními státními úředníky a politiky je hodnocena jako vysoká zejména v rozvojových zemích (např. Angola, Mozambique, Congo). V čele těchto vlád stojí často bývalí vojenští diktátoři, kteří se stali politickými představiteli bez ohledu na transparentnost a odpovědnost, a kteří nízkou všelidovou podporu a zákonnost, jinak nutných k politickému přežití, kompenzují uplácením předních rodinných klanů a zájmových skupin (Volejníková, Linhartová, 2014). U těchto zemí lze tudíž předpokládat větší vliv př́padného snižování diskreční pravomoci úředníků na míru korupce v zemi. Předmětem následující analýzy bude celkem 117 zemí bez ohledu na jejich geografickou příslušnost či politické zřízení a zkoumaným obdobím se stalo období mezi roky 2003 a 2011. Jedná se o soubor zemí, které jsou zahrnuty do hodnocení indexů 
EGDI i CPI po celé analyzované období. Devítiletý časový interval by měl umožnit zachytit dopady změn využití e-governmentu na korupci.

\section{Analýza potenciálního vlivu e-governmentu na míru korupce v zemi}

Spearmanův korelační koeficient pro jednotlivé proměnné všech 117 hodnocených zemí uvádí následující tabulka 1 . Hodnoty, které program Statistica označil za statisticky významné, jsou zvýrazněny tučně. Z tabulky je zřejmé, že mezi veličinami CPI a EGDI je pozitivní korelační vztah jak ve sledovaném roce 2003, tak ve sledovaném roce 2011. V obou letech tedy s rostoucí hodnotou indexu EGDI rostlo současně také hodnocení indexu CPI. Se zvyšující se úrovní využití využití e-governmentu v zemi se zlepšoval i stav korupce.

Tabulka 1: Korelační matice

\begin{tabular}{|c|r|r|r|r|r|r|}
\hline & \multicolumn{1}{|c|}{ CPI 2003 } & CPI 2011 & \% změna CPI & EGDI 2003 & EGDI 2011 & \% změna EGDI \\
\hline CPI 2003 & 1,000000 & 0,935734 & $-0,517411$ & 0,831197 & 0,796237 & $-0,131504$ \\
\hline CPI 2011 & 0,935734 & 1,000000 & $-0,225860$ & 0,840767 & 0,801507 & $-0,135228$ \\
\hline \% změna CPI & $-0,517411$ & $-0,225860$ & 1,000000 & $-0,290771$ & $-0,308495$ & 0,124155 \\
\hline EGDI 2003 & 0,831197 & 0,840767 & $-0,290771$ & 1,000000 & 0,871197 & $-0,334537$ \\
\hline EGDI 2011 & 0,796237 & 0,801507 & $-0,308495$ & 0,871197 & 1,000000 & 0,132332 \\
\hline \% změna EGDI & $-0,131504$ & $-0,135228$ & 0,124155 & $-0,334537$ & 0,132332 & 1,000000 \\
\hline
\end{tabular}

Zdroj: vlastní zpracování

Dopad zejména byrokratické korupce na ekonomickou výkonnost různých zemí je oblíbeným tématem nejrůznějších studií a debat již desetiletí. Silná interakce mezi politiky, úředníky a podnikateli, jejímž cílem je získat nelegální ekonomické renty $\mathrm{z}$ veřejných aktivit, $\mathrm{v}$ mnoha zemích charakterizuje proces rozhodování o veřejných investicích a snižuje jejich hospodářskou výkonnost. Podle studií Mauro (1995, 1996), Leite, Wedeman (1999), Tanzi, Davoodi $(1997,2000)$ a řady dalších má korupce na ekonomickou výkonnost a ekonomický růst státu přesně vyčíslitelný negativní dopad. Empiricky lze doložit, že korupce dlouhodobě nepřináší zemi ekonomickou stabilitu, nebot' deformuje priority vládní politiky včetně cílů měnové a fiskální politiky. Komparace ekonomické vyspělosti země a úrovně vnímání korupce poukazuje na nejchudší země světa jako oblasti s nejvyšši korupční aktivitou. Jedná se především o země afrického kontinentu, které se v celosvětových srovnáních umíst'ují na posledních příčkách konečného pořadí (Volejníková, 2007). Vhledem k výrazným rozdílům $\mathrm{v}$ hodnocené skupině 117 zemí nejen z pohledu míry jejich zasažení korupcí či využívání ICT, ale ekonomické vyspělosti obecně, je vhodné analyzovat případný vliv e-governmentu na korupci u početně menších, avšak více homogenních skupin. Jako kritérium pro rozčlenění 117 zemí do menších celků byl zvolen ukazatel HDP/obyvatele pro rok 2003 dle údajů Světové banky. Skupina analyzovaných zemí tak byla rozdělena na čtyři početně menší skupiny po 29 , resp. 30 zemích. $^{2}$

Pro grafickou interpretaci zkoumaných proměnných byl využit tzv. Bag plot. Jedná se o generalizovaný dvoudimenzionální graf, který slouží ke grafické interpretaci statistických dat. Body v grafu představují kombinace závisle a nezávisle proměnné jednotlivých zemí. Tmavá oblast (tzv. bag) obsahuje 50 \% zkoumaných zemí (mezi prvním a třetím kvartilem) a tmavý čtverec představuje hodnotu mediánu zkoumaných států. Světlemodrá vnější oblast bagu obsahuje ostatní hodnocené státy, které dosahují více odlišných hodnot, nežli země v tmavé oblasti, avšak nejsou odlehlými hodnotami. Mimo tuto oblast se nacházejí odlehlé hodnoty, které jsou v grafu zobrazeny pomocí malých hvězdiček. Bag plot současně ukazuje další charakteristiky zobrazených dat jako je např́klad pozice státu v rámci hodnocených

\footnotetext{
${ }^{2}$ Seznam zemí je uveden v př́loze.
} 
zemí, dále vztah mezi hodnocenými proměnnými, kterou udává orientace bagu (rostoucí bag naznačuje pozitivní vztah mezi hodnocenými proměnnými a klesající bag naznačuje naopak negativní vztah). Obrázek 1 zobrazuje bag plots vytvořených čtyř skupin zemí, jež využívají dat $\mathrm{z}$ roku 2003. Na ose $\mathrm{x}$ je nanesen index EGDI 2003 a na ose y index CPI 2003.

Obrázek 1: Bag plots 2003
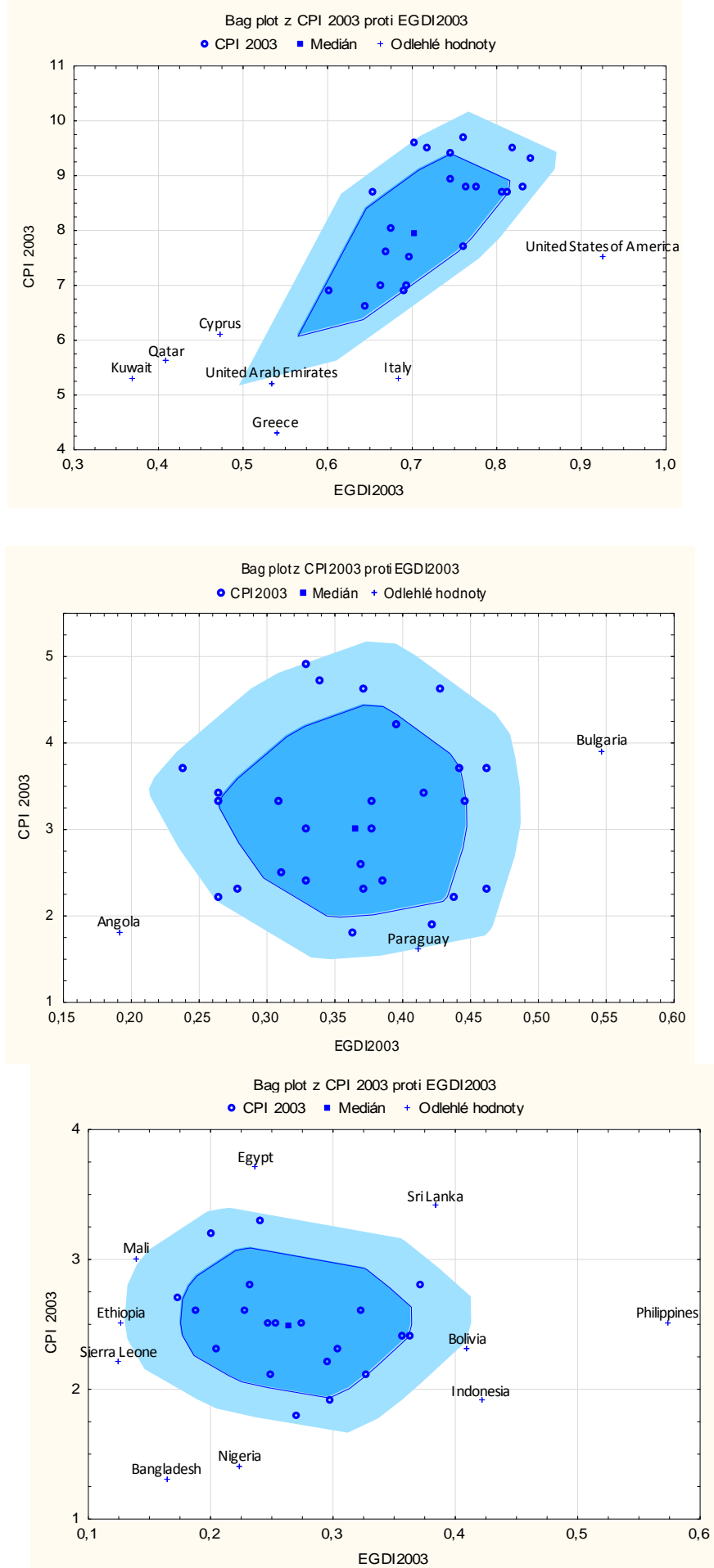

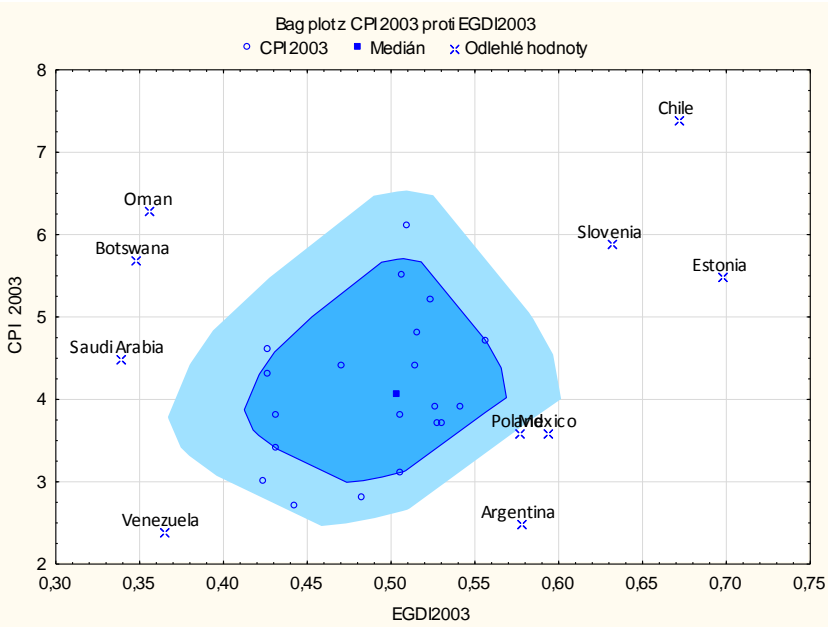

Zdroj: vlastní zpracování s využitím dat (Transparency International, 2003; United Nations, 2003)

Jak již bylo zmíněno $\mathrm{v}$ předchozím textu, vyšší hodnoty EGDI značí větší schopnost využívání IT technologií na poli veřejné správy a vyšší hodnoty indexu CPI značí nižší míru 
korupce v zemi. Sklon bag plotu potvrzuje tento pozitivní vztah mezi proměnnými především u první skupiny ekonomicky nejvyspělejších zemí. Do určité míry obdobný vztah mezi korupcí a e-governmentem lze přisoudit rovněž u ostatních skupin zemí, pouze u třetí skupiny zemí se zmiňovaný vztah nejeví natolik průkazný. Pro analyzovaný rok 2003 tudíž byl potvrzen vliv e-governmentu na míru korupce $\mathrm{v}$ zemi u většiny hodnocených skupin zemí. $\mathrm{V}$ jednotlivých bag plotech došlo $\mathrm{k}$ vytvoření několika klastrů odlehlých zemí, které zaostávají za ostatními státy své skupiny, at' už z pohledu využívání e-governmentu, či hodnocení míry korupce. U skupiny zemí s nejvyšším HDP/obyvatele se jedná např́íklad o Katar, Kuvajt, Kypr, Spojené arabské emiráty, Řecko či Itálii. Tyto státy sice byly na základě údajů o dosahovaném hrubém domácím produktu zařazeny do první skupiny hodnoceních států, avšak v oblasti hodnocených proměnných zaostávají za ostatními členy skupiny. Naopak Spojené státy americké předčily všechny členy první skupiny zemí v hodnocení úrovně e-governmentu ve veřejné správě. Lze říci, že v této zemi informačních a telekomunikačních technologií pro komunikaci se zákazníky veřejné správy využíváno nejčastěji z uvedené skupiny zemí.

Obrázek 2 zobrazuje bag plots s využitím dat roku 2011. Hodnoty indexu EGDI jsou opět vyneseny na ose $\mathrm{x}$ a hodnoty indexu CPI na ose y. Bag plots hodnot roku 2011 dosahuje pozitivního sklonu u všech skupin zemí, což potvrzuje, že mezi proměnnými existuje pozitivní vztah. Došlo opět k vytvoření několika klastrů odlehlých zemí, které se z hlediska zjištěné míry korupce a úrovně e-governmentu liší od ostatních zemí v rámci své skupiny. Napríklad ve skupině zemí s nejnižším HDP na obyvatele došlo k výraznému oddělení Ghany od ostatních zemí skupiny. Ghana zaznamenala ve sledovaném období let 2003 až 2011 nejvýraznější progres $\mathrm{v}$ oblasti využití metod e-govrenmentu $\mathrm{v}$ oblasti veřejné správy. $\mathrm{V}$ analyzovaném odbobí let dosáhla z hodnoty indexu EGDI 0,241 v roce 2003 na hodnocení 0,712 v roce 2011 a zaznamenala tak nárůst o celých $95 \% \mathrm{v}$ úrovni využití e-governmentu. Ve zmíněné zemi došlo rovněž ke snížení míry korupce o více než $45 \%$. Za zmínku stojí rovněž vývoj proměnných Bangladéše, která ve sledovaném období zaznamenala zlepšení ukazatele e-governmentu o téměř $82 \%$ za současného zlepšení hodnoty ukazatele korupce o $104 \%$.

Obrázek 2: Bag plots 2011
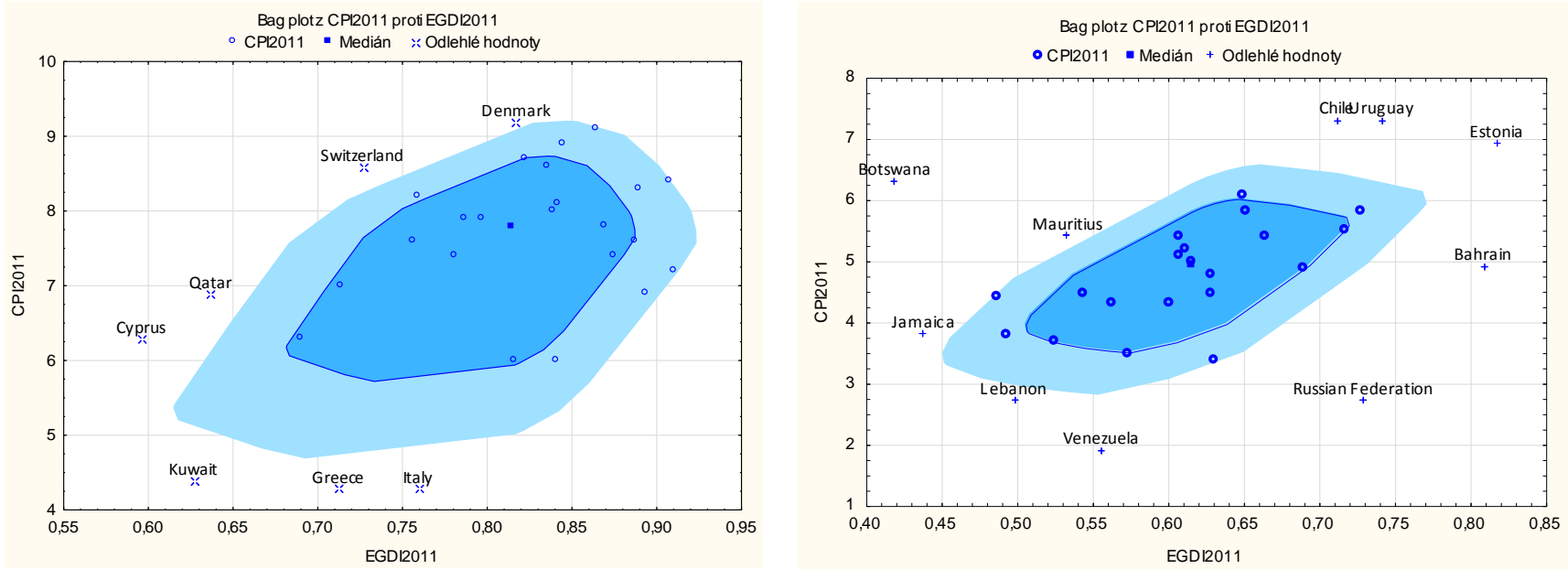

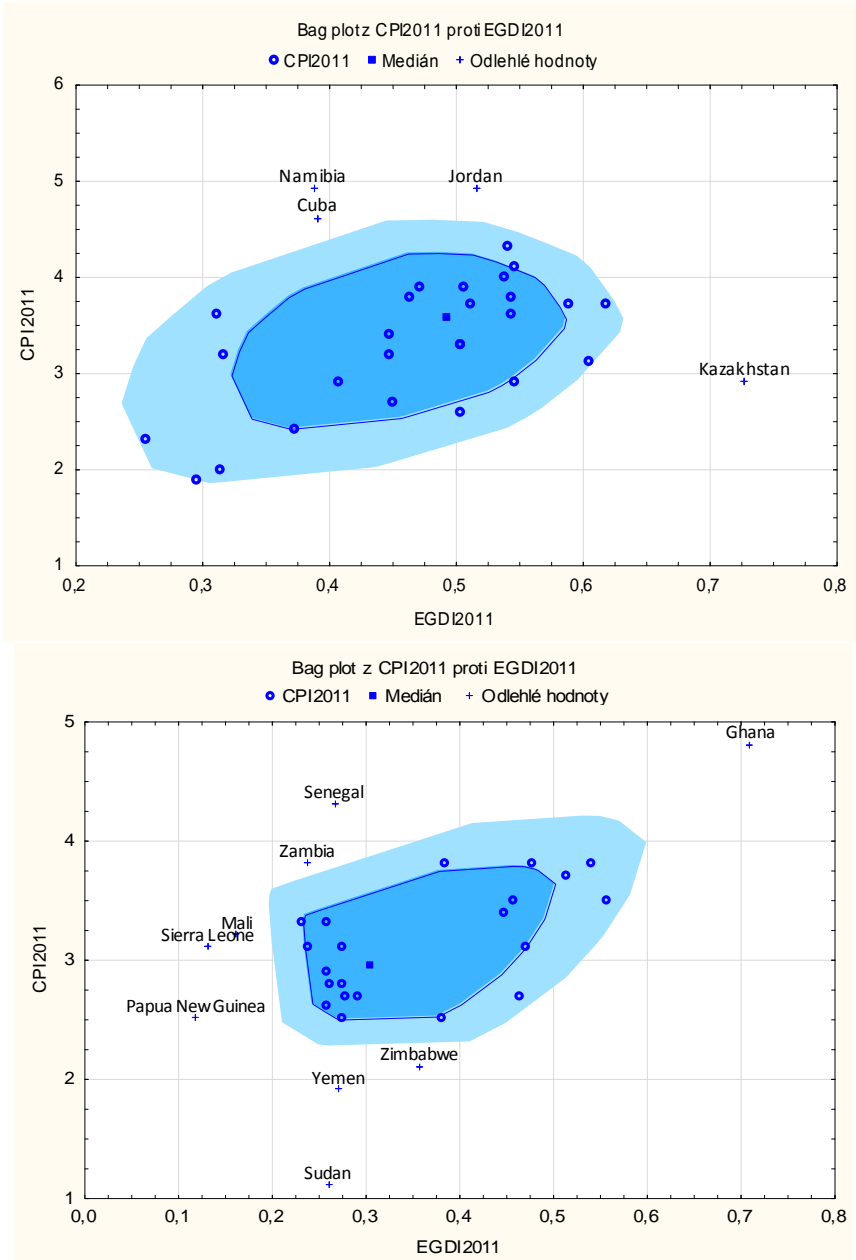

Zdroj: vlastní zpracování s využitím dat (Transparency International, 2011; United Nations, 2011)

K ověření závislosti korupce na využití e-governmentu byla rovněž využita následující regresní funkci vycházející z metody nejmenších čtverců: (Mistry, Jalal, 2012)

$$
y=\alpha+\beta * x+\varepsilon
$$

Parametr x označuje nezávisle proměnnou, v našem prŕípadě tedy využití e-governmentu (index EGDI) a parametr y označuje závisle proměnnou, tedy míru korupce (index CPI). Parametr $\alpha$ určuje vzdálenost průsečíku regresní přímky s osou y od počátku souřadnic (hodnota regresní funkce pro $\mathrm{x}=0$ ). Parametr $\beta$ se nazývá regresní koeficient. Udává, o kolik se změní závisle proměnná veličina, zvětší-li se hodnota nezávisle proměnné o jednotku. Symbol $\varepsilon$ je reziduální rozptyl, což je grafické znázornění vzdálenosti bodů od regresní prímky.

Pro odhad změny v míře korupce vyvolaný změnou e-governmetu v zemi lze využít následující model:

$$
\Delta \text { Korupce }=\alpha+\beta^{*} \Delta \text { e-government }+\varepsilon,
$$

kde $\Delta$ Korupce je změna Indexu vnímání korupce mezi roky 2003 a 2014 a $\Delta$ e-government je změna v E-government development indexu ve stejném období. 
Obrázek 3 zobrazuje lineární regresní modely znázorňující procentní změnu EGDI mezi lety 2003 a 2011 na vodorovné ose a procentní změnu CPI v letech 2003 a 2011 na svislé ose. Tento obrázek v zachycuje vývoj CPI a EGDI během období odběru vzorků. Daty je proložena lineární regresní př́mka doplněná o pás spolehlivosti. Regresní př́ímky dokládají, že zřejmě ne všechny země, které zvýšily hodnotu EGDI zaznamenaly současně pokles korupce. Nicméně, lineární regresní př́mka všech skupin zemí kromě zemí druhé skupiny, má alespoň mírně kladný sklon, který potvrzuje pozitivní působení využití e-governemntu na hodnocení míry korupce v hodnocených zemích.

Obrázek 3: Lineární regresní model pro změny veličin v letech 2003-2011
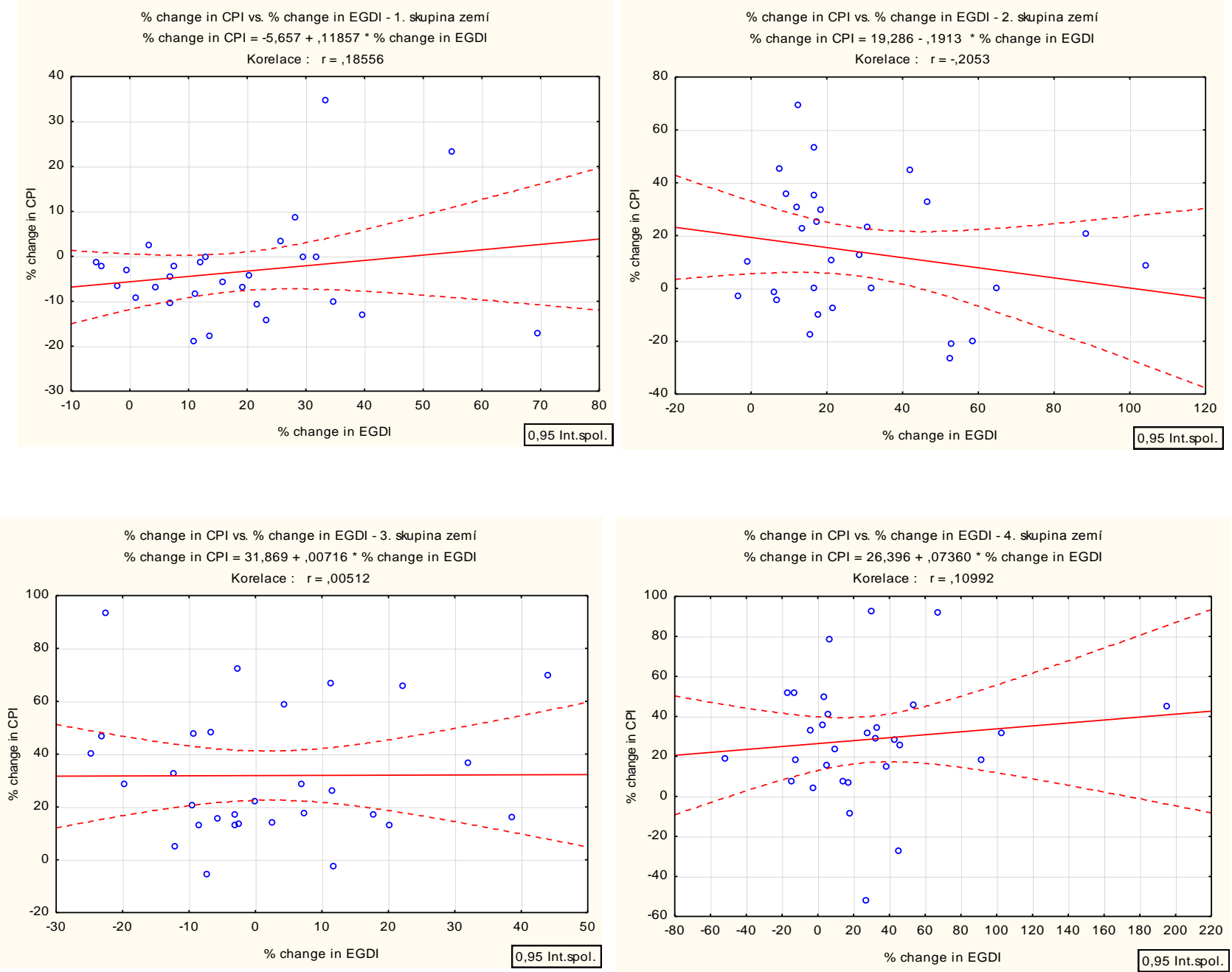

Zdroj: vlastní zpracování s využitím dat (Transparency International, 2003, 2011; United Nations, 2003, 2011)

Výraznější pozitivní vliv e-governmentu na míru korupce v zemi byl prokázán u první a čtvrté skupiny zemí. U zemí s nejvyšším HDP/obyvatele bylo pro sledované období prokázáno, že při neměnných podmínkách a ostatních proměnných vede jednoprocentní změna indexu EGDI téměř $0,12 \%$ změně indexu CPI. Jinými slovy, pokud dojde ke zlepšení hodnocení e-governmentu v zemi o 1 \%, dojde ke zlepšení hodnocení korupce v zemi o 0,12 \%. Naopak u skupiny zemí s nejnižším HDP/obyvatele bylo pro sledované období let zjištěno, že jednoprocentní změna indexu EGDI měla za následek více než $0,07 \%$ změnu indexu CPI. Tedy zlepšení hodnocení úrovně e-governmentu v zemi se odrazilo na lepším hodnocení míry korupce v zemi o $0,07 \%$. 


\section{Závěr}

Př́spěvek se zabývá zkoumáním existence vztahu mezi korupcí a e-governmentem, současně pak otázkou, zda změny ve využívání informačních technologií působí na změnu míry korupce $\mathrm{v}$ zemi. Za účelem přezkoumání těchto vztahů byla definována hypotéza, jejíž pravdivost byla ověřována za pomoci empirických modelů. Využitím těchto modelů bylo zjištěno, že používání informačních technologií a rozvoj e-governmentu přispívá ke snižování míry korupce ve většině zemí.

S využitím korelačního koeficientu a regresní analýzy byl u většiny států potvrzen pozitivní vliv využití metod e-governmentu na snižování míry korupce. Tento pozitivní efekt e-governmentu nebyl prokázán u všech zkoumaných zemí. U některých států bylo i přes zvýšenou úroveň využívání metod e-governmentu zaznamenáno zhoršení stavu korupce. Toto zjištění pouze potvrzuje známou skutečnost, že prŕíčin korupce existuje celá řada, vyskytuje se $\mathrm{v}$ různých oblastech nejen veřejné správy a nabývá různých podob. $Z$ tohoto důvodu nelze vytvořit jednoduchý recept pro boj s korupcí, jež by byl účinný ve všech zemích po celém světě, napříč politickými uspořádáními či vládními zř́zeními zemí. Nicméně lze říci, že využívání metod e-governmentu jako prostředku pro omezování korupčních příležitostí ve veřejné správě je jednou z dobrých cest za snižováním korupce v řadách úředníků.

Pro sledované období let 2003 až 2011 byl prokázán pozitivní vliv zejména u ekonomicky vyspělejších zemí. U této skupiny států bylo prokázáno, že jednoprocentní zvýšení indexu EGDI ve sledovaném období zapř́íčinilo snížení korupce (zvýšení hodnoty indexu CPI) o $0,12 \%$. U skupiny zemí s nejnižším HDP na obyvatele byl rovněž prokázán vliv e-governmentu na míru korupce v zemi jako u zemí ekonomicky nejvyspělejších. Provedená analýza vlivu působení e-governmentu na korupční prostředí v zemi tak navazuje na již existující studie (např. Mistry a Jalal, 2012 či Kimbro, 2002 a Kim, 2007) a potvrzuje možné snižování míry korupce v zemi za pomoci využití metod e-governmentu.

$\mathrm{S}$ ohledem na zjištěné výstupy př́spěvek poukazuje na nutnost dalších výzkumů v oblasti dopadu e-governmentu na korupci. Budoucí výzkumy v této oblasti by mohly zkoumat tento vztah s cílem poskytnout rámec zaměřený na efektivní realizaci e-governmentu jako součásti protikorupční strategie, která povede ke skutečnému a znatelnému snížení korupce.

\section{Literatura}

[1] BHARGAVA, V. a E. BOLONGAITA, 2004. Challenging corruption in asia: case studies and a framework for action. Washington, DC: The International Bank for Reconstruction and Development/The World Bank [online]. [vid. 29. dubna 2015]. Dostupné Z: https://openknowledge.worldbank.org/bitstream/handle/10986/ 15069/275800PAPER0Challenging0corruption.pdf? sequence $=1$

[2] BHATNAGAR, S, 2003. Transparency and Corruption: Does E-Government Help? CHOGM 2003 Report [online]. [vid. 29. dubna 2015]. Dostupné z: http://unpan1.un.org/intradoc/groups/public/documents/unpan/unpan035963.pdf

[3] HELlmANN, J., G. JONES a D. KAUFMANN, 2009. Seize the state, seize the day: State capture, corruption and influence in transition economies [online]. [vid. 29. dubna 2015]. Dostupné z: http://worldbank.org/wbi/governance

[4] HOPPER, T., M. TSAMENYI, S. UDDIN a D. WICKRAMASINGHE, 2009. Management accounting in less developed countries: what is known and needs knowing. Accounting, Auditing \& Accountability Journal [online]. 22(3), 469-514 [vid. 29. dubna 2015]. Dostupné z: http://dx.doi.org/10.1108/09513570910945697 
[5] JAIN, A. K., 2001. Corruption: A review. Journal of Economic Surveys [online]. 15(1), 71-121 [vid. 29. dubna 2015]. Dostupné z: http://dx.doi.org/10.1111/1467-6419.00133

[6] KIM, C., 2007. A cross-national analysis of global E-government. Public Organization Review [online]. 7(10), 317-329. Dostupné z: http://dx.doi.org/10.1007/s11115-0070040-5

[7] KIMBRO, M., 2002. A cross-country empirical investigation of corruption and its relationship to economic, cultural, and monitoring institutions: an examination of the role of accounting and financial statements quality. Journal of Accounting, Auditing, and Finance [online]. 17(4), 325-349 [vid. 29. dubna 2015]. Dostupné z: http://dx.doi.org/10.1177/0148558X0201700403

[8] MAURO, P., 1995. Corruption and growth. The Quarterly Journal of Economics [online]. 110(3), 681-712 [vid. 29. dubna 2015]. Dostupné z: http://dx.doi.org/10.2307/2946696

[9] MAURO, P., 1997. Why Worry About Corruption? IMF Economic Issues, 6, 19 p. ISBN 1-55775-635-X.

[10] MISTRY, J. J., 2012. The Role of eGovernance in mitigating corruption. Accounting and the Public Interest [online]. 12(1), 137-159 [vid. 29. dubna 2015]. Dostupné z: http://bit.ly/Yn2giX

[11] MISTRY, J. J. a A. JALAL, 2012. An empirical analysis of relationship between egovernment and corruption. The International Journal of Digital Accounting Research [online]. 12, 145-176 [vid. 29. dubna 2015]. Dostupné z: http://www.uhu.es/ijdar/10.4192/1577-8517-v12_6.pdf

[12] SHIM, D. a T. H. EOM, 2008. E-government and anti-corruption: empirical analysis of international data. International Journal of Public Administration [online]. 31(3), 298316 [vid. 29. dubna 2015]. Dostupné z: http://dx.doi.org/10.1080/01900690701590553

[13] SHIM, D. a T. H. EOM, 2009. Anticorruption effects of information communication and technology (ICT) and social capital. International review of administrative sciences, 75(1), 99-116. ISSN 0020-8523

[14] SINGH, G., R. PATHAK, R. NAZ a R. BELWAL, 2010. E-governance for improved public sector service delivery in india, ethiopia and fiji. International Journal of Public Sector Management [online]. 23(3), 254-275 [vid. 29. dubna 2015]. Dostupné z: http://www.emeraldinsight.com/journals.htm?issn=0951-3558

[15] TANZI, V., 1998. Corruption around the world: causes, consequences, scope and cures. International Monetary Fund, Working Paper, 98/63 [online]. [vid. 29. dubna 2015]. Dostupné z: http://www.imf.org/external/pubs/ft/wp/wp9863.pdf

[16] TORRES, L., V. PINA a B. ACERATE, 2006. E-governance developments in european union cities: reshaping government's relationship with citizens. Governance [online]. 12(2), 277-302 [vid. 29. dubna 2015]. Dostupné z: http://dx.doi.org/10.1111/j.14680491.2006.00315.x

[17] TRANSPARENCY INTERNATIONAL, 2003. Corruption perceptions index 2003 [online]. [vid. 29. dubna 2015]. Dostupné z: http://www.transparency.org/ research/cpi/cpi_2003

[18] TRANSPARENCY INTERNATIONAL, 2011. Corruption perceptions index 2011 [online]. [vid. 29. dubna 2015]. Dostupné z: http:// http://www.transparency.org/cpi2014/interactive/ 
[19] UNITED NATIONS, 2003. United Nations e-government survey 2003 [online]. [vid. 29. dubna 2015]. Dostupné z: http:// http://unpan1.un.org/intradoc/ groups/public/documents/un/unpan016066.pdf

[20] UNITED NATIONS, 2011. United Nations e-government survey 2011 [online]. [vid. 29. dubna 2015]. Dostupné z: http://www.un.org/en/development/ desa/publications/connecting-governments-to-citizens.html

[21] VOLEJNÍKOVÁ, J., 2007. Korupce v ekonomické teorii a praxi. Praha: Profess Consulting. ISBN 978-80-7259-055-1.

[22] VOLEJNÍKOVÁ, J. a V. LINHARTOVÁ, 2014. Macro-economic Aspects of Corruption. 1. vyd. Saarbrücken: LAP Lambert Academic Publishing AG \& Co. KG, ISBN 978-3-659-52992-4.

[23] WORLD BANK. Data and research [online]. [vid. 29. dubna 2015]. Dostupné z: http://econ.worldbank.org/external/default/main?pagePK=64165259\&piPK=64165421\&t heSitePK=469372\&menuPK=64216926\&entityID=000158349_20080908113828 


\section{Př́loha}

Seznam zkoumaných zemí dle HDP/obyvatele v USD:

1. skupina zemí

Luxembourg, Norway, Iceland, Switzerland, Qatar, Ireland, Denmark, United States of America, United Arab Emirates, Sweden, Netherlands, United Kingdom, Finland, Austria, Belgium, Canada, Japan, Kuwait, Franc, Germany, Australia, Italy, Singapore, New Zealand, Spain, Cyprus, Greece, Israel, Portugal.

2. skupina zemí

Slovenia, Bahrain, Czech Republic, Saudi Arabia, Trinidad and Tobago, Oman, Slovakia, Hungary, Estonia, Croatia ,Poland, Lithuania, Mexico, Chile, Latvia, Turkey, Argentina, Malaysi, Venezuela, South Africa, Lebanon, Russian Federation, Botswana, Uruguay, Mauritius, Brazil, Romania, Costa Rica, Panama, Jamaica.

3. skupina zemí

Bulgaria, Cuba, Kazakhstan, Dominican Republic, Namibia, Serbi, Colombia, Tunisia, Belarus, Algeria, Ecuador, Bosnia and Herzegovina, Albania, Iran, Peru, Thailand, Jordan, Guatemala, Morocco, Ukrain, China, Congo, Angola, Armenia, Syrian Arab Republic, Azerbaijan, Paraguay, Honduras, Indonesia, Egypt.

4. skupina zemí

Sri Lanka, Philippines, Nicaragua, Bolivia, Cameroon, Yemen, Republic of Moldova, Nigeria, Papua New Guinea, Senegal, India, Zambia, Viet Nam, Pakistan, Sudan, Kenya, Ghana, Kyrgyzstan, Zimbabwe, Mali, Bangladesh, United Republic of Tanzania, Sierra Leone, Uganda, Mozambique, Madagascar, Malawi, Ethiopia. 